\title{
On the Phonetic Consonance in Quranic Verses-Final Fawāṣil
}

\author{
Nadhim Abdulamalek Aldubai \\ Department of Languages \& Translation \\ Taibah University, Saudi Arabia \\ E-mail: nadhim92@gmail.com
}

Doi:10.7575/aiac.alls.v.6n.3p.61

Received: 04/01/2014

URL: http://dx.doi.org/10.7575/aiac.alls.v.6n.3p.61

Accepted: 16/03/2015

\begin{abstract}
The present research aims to discuss the phonological patterns in Quranic verse-final pauses (fawāsil) in order to provide an insight into the phonetic network governing the symmetrical and the asymmetrical pauses (fawassil) in terms of concordance (al-nasaq al-șawti). The data are collected from different parts of the Quran and are investigated with focus on three major phonetic criteria: the phonetic features of the fawāssil, the fășilah shift from the surrounding fawāșil, and the semantically-oriented sounds. The discussion concludes that the Quranic fawāșil are either completely symmetrical in the fășilah-final syllables, semi-symmetrical in the fäșilah final syllables. It also reveals that some fawassil share the same foot (taf'ilah) and rhythm $(a l-i q \bar{a})$, while others have different foot and rhythm, but they are similar in some sounds. Other fawāssil are similar in the foot but different in sounds, while others are similar in the last two sounds. The last category is when the Surah ends with a different fāssilah from all the previous fawāșil. The analysis also reveals that the fawassil are semantically-oriented in the sense that they are not only concerned with ornamentation and undulation of the sounds but they also convey deep meanings which move the hearer to listen carefully and to abide by the Quranic teachings.
\end{abstract}

Keywords: taf'ilah, fawāṣil, cluster, consonance, Quranic, phonetic

\section{Introduction}

The verse-final pause (henceforth, fāṣilah (sing), fawāṣil (pl)) refers to the last word in the verse. The textual function of făsilah is identical to rhyme in poetry and assonance in prose. According to Abu Omer Al-Dāni ( died 1052), cited in Al-Zarkashi (1957,1:53-54), the fāssilah is the end of a clause or a sentence within a verse. However, Al-Baqillāni (died 1051) (1997:180) asserts that the fășilah is the end of the verse. Al-Rummani (1956:97) defines the fawassil as "symmetrical sounds that are similar in syllables and lead to better understanding of meaning". He draws a distinction between end-of-verse pauses (fawāssil) and assonance (saj') by indicating that the fawasșil are rhetorical and are governed by their semantic significations. However, assonance governs the meanings. The fawasşil can appear at the end of a long verse, in the middle or after a one-word verse with a purpose of giving ornamentation to the verse and a specific meaning to the reader. The fawāṣil are effectively significant in making Quran different from poetry and prose. Taha Hussein (died 1973), cited in Lawrence (2005:64) rightly claims that Arabic composition should be divided into three categories, prose, poetry and Quran; saj' forms a part of prose but the Quran is a category of its own.

According to Abdul-Raof (2012:83), the school of linguistic Quranic exegesis has been the most robust exegetical technique that had evolved since the formative phase in the 1st/7th century and span to the 21 st century. This was linked to the notion of inimitability of Quranic discourse (i'jaz al-Quran). The inimitability-oriented analysis of Quranic genre is hinged upon linguistic and levels of analysis. However, Abdul-Raof does not mention the fact that there is another level of analysis that is also related to the notion of inimitability of Quranic discourse. This is the phonetic level of language which we are primarily concerned with. For Abdul-Raof (ibid:84), the historical development of linguistic exegesis can be traced back to the early stages of the formative phase during the 1st/7th century where both the Madinah school of exegesis founded by Ubai b. Kacb and the Kufah school of exegesis founded by Ibn Mascud showed interest in the linguistically-based and phonetically-based variant modes of reading approach to Quranic exegesis. However, it was during the early decades of the $2 \mathrm{nd} / 8$ th century that linguistic exegesis had taken a new turn. During this stage, interest in linguistic exegesis was more evident. Exegetes of the Andalus school (3rd/9th -8 th/14th century were also interested by linguistic exegesis. During the 20th and the 21 st centuries, the majority of scholarship in Quranic exegesis has been linguistically-oriented by both mainstream and non-mainstream exegetes.

According to Lawrence (2005:64), Boullata (1988) gives Sayyid Qutb (died 1966) a credit for his aesthetic appeal of the Quran and for his exposition of tașivir (imagery) which underlies the distinctive style of the Quran. Lawrence (2005:65) also claims that A. J. Arberry (died 1969) stands for his sensitivity to the elliptical but crucial element of the Quranic language that Lawrence calls its surfeit of meaning; it is at the heart of what Maramduke Pickthall termed 'that inimitable symphony'. Lawrence (2005:78) discusses the dilemma of the Quran translators. "Even Arabic native speakers familiar with Arabic cannot easily translate 'al-rahman al-Rahim'. They fail to do so, however, because unless 
the two words somehow rhyme with each other in translation as they do in original Arabic, they do not convey the sense of the Quranic phrase'al-rahman al-Rahim'". This shows the importance of the fawāsil of the verses in conveying a special meaning through the rhyme to the hearer.

The following points are observed to highlight the melodious aspect in the fawāṣil and to consider the requirements of the rhyme and the consonance harmony:

(i) The fawāssil are precisely determined by pauses: If the reader continues to read the two verses together without a pause, the rhyme will be disturbed. An example of this is in the table below:

Table 1. Fawāṣil in the sukuun position (As-Saffat, verses:9,10,11)

\begin{tabular}{|c|c|}
\hline puase & Continuous reading \\
\hline Gaðaabun waas'ib & Gaðaabun waas'ibun \\
\hline Jihaabun ðaaqib & fihaabun ðaaqibun \\
\hline t'iinin laazib & $t^{\uparrow}$ iinin laazibin \\
\hline
\end{tabular}

The fawāssil /waas'ib, ðaaqib, laazib/ will be transformed in continuous reading to /waas'ibun, ðaaqibun, laazibin/ respectively. Thus, It is worthwhile to note that the nunation (al-tanween) is not taken into consideration in the present analysis because nunation is: (i) an added phonetic feature to the word-final sound under investigation, and (ii) it is only employed for an aesthetic function to achieve the rhetorical purpose of assonance (al-saja). In support to what has been claimed above, Anis (1976:32) observes that "to pause in sukuun in /Pinna Paft'ajnaaka lkaw wanћar, Pinna Jaani?aka huwal Pabtar/, is to achieve the musical harmony."

(ii) Most of the fawāșil end with vowels released into $/ \mathrm{m} / \mathrm{and} / \mathrm{n} /$ so that the reciter will be able to chant and intone. AlZrakashi (1957, 1:20) quoting Sibawayh "if an Arab wants to intone, he releases the vowels into $/ \mathrm{m} / \mathrm{and} / \mathrm{n} / . "$ The following table shows the frequency of $/ \mathrm{m}$ and $/ \mathrm{n} /$ in some Quranic chapters:

Table 2. Frequency of of $/ \mathrm{m} /$ and $/ \mathrm{n} /$ in some Surahs in the Quran

\begin{tabular}{|c|c|c|c|}
\hline & Total verses & $\mathrm{n}$ & $\mathrm{m}$ \\
\hline albaqara & 286 & 192 & 54 \\
\hline Aal Imraan & 200 & 12 & 30 \\
\hline alnisaa & 176 & 17 & 56 \\
\hline Almu'minuun & 118 & 116 & 2 \\
\hline alrrahmaan & 78 & 69 & 7 \\
\hline
\end{tabular}

The following changes are made in the structure of the fawāsil in order to reach harmonious ornamentation of the fawāṣil.

Forwarding and backwarding the fạșilah in the verse. /qaaluu Paamanna birabbi haruuna wa muusaa/ (Taha verse:70) compared to /rabbi muusaa wa haruuna / (al-Shu'raa verse:48).

Addition of a sound to rhyme with other verses: /wa taðৎunnuna billah að`ð`unuuna/, (Al-Ahzaab, verse:10)./að`ð`unuuna/ is originally /aðৎð`unuun/ without a vowel. It is released into a vowel to rhyme with the

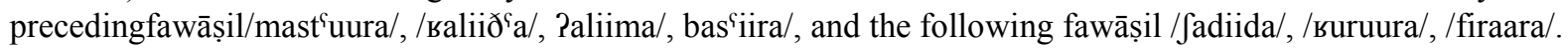


Deletion of the vowel /ii/ in /wallajli Piðaa jasr/(Al-Fajr, verse:4) instead of /jasrii/ to rhyme with /Ralfadzr/. / $\mathrm{Safr} /$,

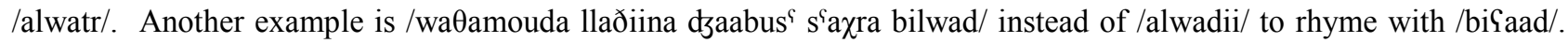
/RalYimaad/, /Ralbilaad/, /RalPawtaad/ etc. Al-Burhaan (1957:62).

Nunation of the non-nunated words such as /wa Pakwabin kaanat qawaariir/ (Al-Insan, verse:15/r/ was released into a vowel /qawaariira/ to rhyme with the preceding words: /suruura, hariira, zamhariira, taðliila/ and the following words /taqdiira, zandzabiila, salsabiila/.

Deletion of the addressee pronoun $/ \mathrm{k} /$ as in: /wad $\mathrm{d}^{\varsigma} u \hbar a a$, wallajli Piðaa sadzaa, ma waddaSaka rabbuka wa maa qalaa/ (Al-Dhuha, verses:1-3), /qalaa/ is originally/qalaaka/. However, the / $\mathrm{k} /$ is deleted to rhyme with all the surrounding words ending with the long vowel /aa/.

Singularization of what is originally plural as in / Rinna lmuttaqqiina fii dzannatin wa nahar/ (al-Qamar, verse:34, /nahar/ (sing) is originally / Ranhaar/ (pl). However, it is singularized to rhyme with the following word /muqtadir/.



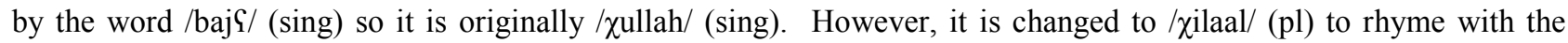
surrounding words.

Changing the tense from past to present as in /fafriiqan kaððabtum (past) wa fariiqan taqtuluun (present)/(Al-Baqara, verse:87). The present tense verb is originally /qataltum/ but it is changed to the present tense to rhyme with the surrounding words.

\section{The present analysis}

The present research aims to discuss the phonological patterns in Quranic verse-final pauses (fawāșil) in order to provide an insight into the phonetic network governing the similar and different pauses (fawāșil) in terms of concordance (al-nasaq al-șawti). The current phonetic analysis investigates three major phonetic criteria:

Phonetic features of the fawāṣil,

fāṣilah shift from the surrounding fawāșil, and

semantically-oriented sounds.

\subsection{Phonetic features of the fawāṣil}

This is a pattern that comprises sounds that share several phonetic distinctive features. In different contexts in the Quran, a number of verses rhyme together in one group where fawāṣil-final sounds share many distinctive features. This type of pauses (fawāșil) can be hinged up together and named "cluster". The cluster phonetic pattern can be classified as follows:

Since this work focuses on the phonetic features of the fawāșil, it is worthwhile noted that the IPA phonetic transcription, rather than transliteration, will be used to transcribe verses.

2.1.1 The pharyngealized sounds cluster

This is a pattern in which the pharyngealized sounds come sequentially. The pharyngealized sounds include $/ \mathbf{s}^{\mathrm{s}} /, \mathrm{t}^{\mathrm{\varsigma}} /$, $/ \mathrm{\nearrow}^{\varsigma} /$, and $/ \mathrm{d}^{\mathrm{C}} /$, as discussed below:

Table 3. Pharyngealized sounds pattern (Fușilat, verses:48-51)

Phonetic transcription

ending

wađalla Sanhum ma kaanu jadৎuuna min qablu wa ðৎannu maalahum min maћiis

$S^{\varsigma}$

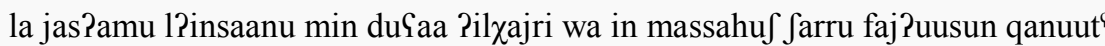

$t^{\varsigma}$

wa la?in Paðaqnaahu raћmatan minna min baৎdi đarra?a massathu lajquulanna haaða lii wa ma $ð^{\varsigma}$

Pað'unnus saaSata qaaPimatan wa la?ir rudziStu ?ila rabbi Pinna lii Sindahu lalhusna falanunabbiجan nallaðiina kafaruu bima Samiluu wa lanuðiiqannahum min ৎaðaabin ваliiðৎ

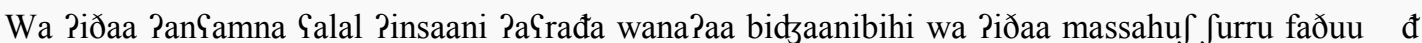
duYaain Sariiđ 
All the $/ \mathrm{s}^{\mathrm{s}} /, / \mathrm{t}^{\mathrm{f}} /, / \delta^{\mathrm{s}} /$ and $/ \mathbb{d} /$ sounds are characterized by pharyngealization. The above (fawāssil) belong to the same phonetic feature of pharyngealization. Ateeq (2009) posits that not only they are characterized by pharyngealization, but also they have almost the same place of articulation. They are denti-alveolar except for the / $₫$ / which is dental, a place of articulation which is adjacent to the alveolar ridge. Looking at the sequence of the fawāșil will reveal another phonetic feature. The sounds are distributed into four phonetic features i.e. friction, plosiveness, voicing and devoicing according to the sequences of the verses.

$/ \mathrm{s}^{\mathrm{s}} /=$ voiceless pharyngealized denti-alveolar fricative

$/ t^{\mathrm{s}} /=$ voiceless pharyngealized denti-alveolar plosive

$/ \Upsilon^{\varsigma} /=$ voiced pharyngealized dental fricative

$/ \mathbb{d} /=$ voiced pharyngealized denti-alveolar plosive

It is important to note that in our analysis of this particular phonetic pattern we have focused, following Ateeq (2009), that only on the pharyngealized sounds rather than their counterpart pharyngeal sounds. The sounds also alternate between two manners of articulation i.e. plosive and fricative. Moreover, two end-of-words sounds are voiced and two are voiceless. The phonetic dichotomy in the verses caused a melodious rhythmic waves as shown below:

/đ/ $\quad=$ voiced plosive

$/ \delta / \quad=$ voiced fricative

$\mid \mathrm{t}^{\mathrm{s}} / \quad=$ voiceless plosive

$/ \mathrm{s}^{\mathrm{s}} / \quad=$ voiceless fricative

From the above discussion, one can observe that there are four types of ascending assonance. This is explained below: The first assonance level is represented by the first pause $/ \mathbf{s}^{\mathrm{s}} /$ a voiceless fricative which is the least audible sound compared to the other sounds. The second phonetic rhythmic level is represented in the second pause $/ \mathrm{t}^{\mathrm{t}} /$, a voiceless plosive, which is more audible than the friction. The third phonetic rhythmic level is represented in the third pause $/ \delta^{\varsigma} /$, a voiced fricative sound, which is more audible than the voiceless sounds.

The fourth level is / $\mathbb{d} /$, a voiced plosive, which is the strongest among all the previous sounds. It goes without saying that this sequence graded the sequence from the lowest to the highest rhythm.

2.1.2 The concussion sounds cluster

By the concussion sound we mean the audibly-released sound which is called in Arabic as (qalqalah). The concussion sounds include /q, t, b, d子, $\mathrm{d} /$ as discussed in the following verses:

Table 4. The qalqalah sounds cluster (Al-Jin, verses:4-6)

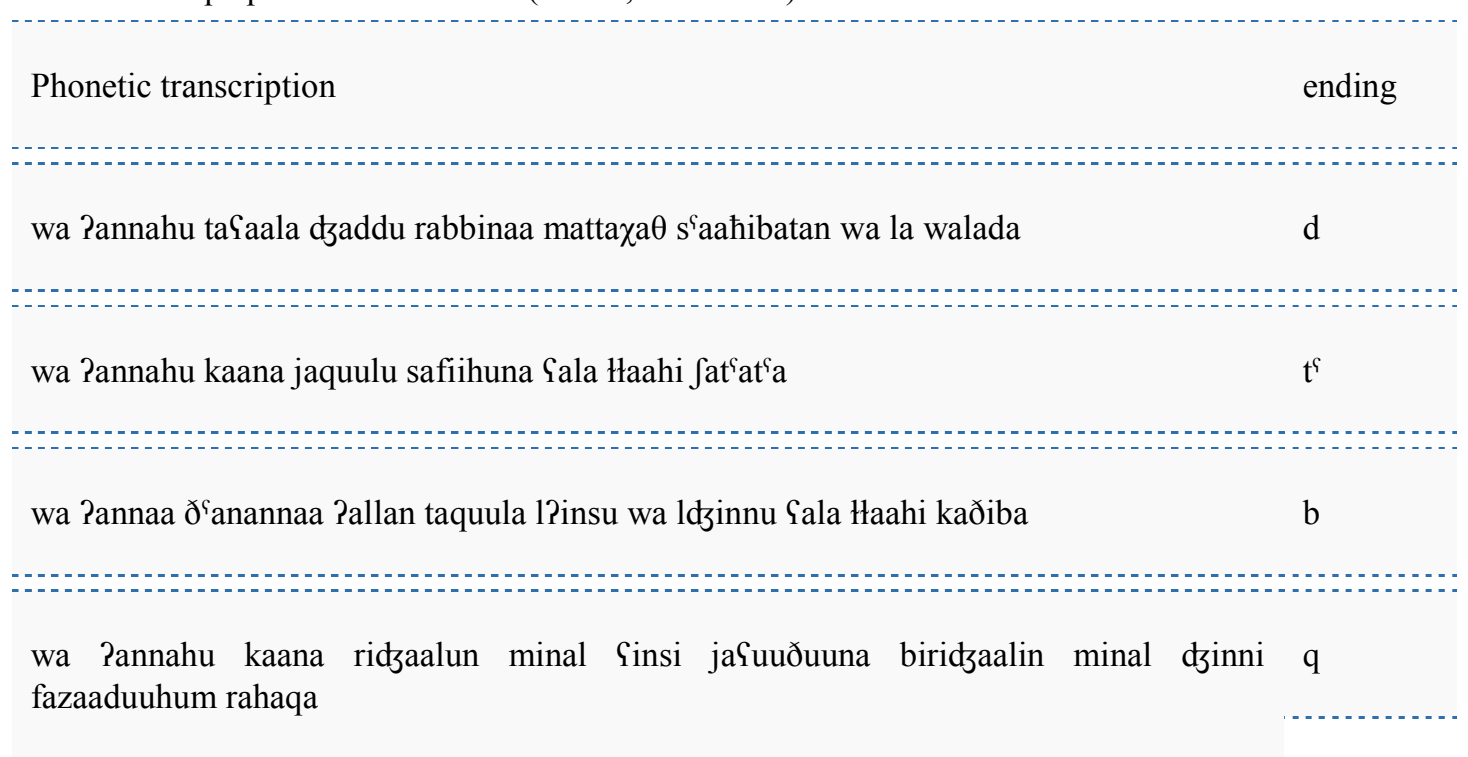

Table 1.4 displays examples that end in concussion sounds $/ \mathrm{d} /, / \mathrm{t} /, / \mathrm{b} /$, and $/ \mathrm{q} /$; in other words, these sounds are all audibly released, (Ateeq, 2009). The sequence is chained with a phonetic pattern which fulfills the alteration from voicing and devoicing. /d/ is voiced while /t/ is devoiced; /b/ is voiced while /q/ is devoiced. The sequential pattern between voicing and devoicing gives a melody to the phonetic contour. All the sounds belong to one manner of articulation i.e. plosiveness, which gives a strong impact on the receiver to achieve the required semantic representation. 


\subsubsection{The nasal sounds cluster}

The nasal sounds $/ \mathrm{n}, \mathrm{m} /$ are the most frequent sounds in the fawāșil of the Quranic verses. The alternation between /n/ and $/ \mathrm{m} /$ is discussed in the following verses:

Table 5. The nasal sounds cluster (Al-Waqi'a, verses: 48-53.)

\begin{tabular}{|c|c|}
\hline Phonetic transcription & ending \\
\hline qul Pinnal Pawwaliina wal Paaxiriin & $\mathrm{n}$ \\
\hline lamadzmuuSuuna Pila miqaati jawmin maSluum & $\mathrm{m}$ \\
\hline $\begin{array}{l}\text { Oumma Pinnakum } \\
\text { Paijuha đđaalluun al mukiððbuun }\end{array}$ & $\mathrm{n}$ \\
\hline
\end{tabular}

la Paakiluna min Jadzarin minzaqquum

$\mathrm{m}$

famaali?iuna minha lbut'uun

$\mathrm{n}$

fa Saaribuuna Salajhi minal hamiim

$\mathrm{m}$

The nasal sounds $/ \mathrm{m} /$ and $/ \mathrm{n} /$ are sequenced in a raw giving the nasal phonetic pattern a strong rhythmic contour on the receiver. In addition to this, all the sounds are voiced and they articulated from adjacent places of articulation. Thus, the phonetic cluster contains different phonetic connections: nasalization, voicing and adjacent places of articulation. (Ateeq, 2009).

\subsubsection{The liquid sounds cluster}

The liquid sounds are $/ \mathrm{m} /, / \mathrm{n} /, / 1 / / \mathrm{r} /$, as shown in the following verses:

Table 6. The liquid sounds cluster (Al-Nur, verses:34-37)

Phonetic transcription

ending

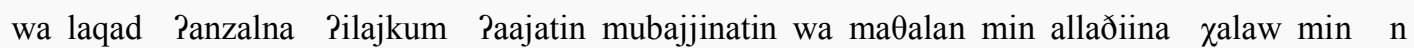
qablikum wa mawৎiað`́tan lilmuttaqiin

- . - . - . . . . .

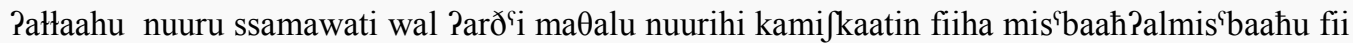
zudzaatin Pazzudzaadzatu kaPannaha kawkabun durrijjun juqadu min fadzaratin mubaarakatin zajtuunati la Sarqijjatin wa laa sarbijjatin jakaadu zajtuha juđii?u wa law lam tamsashu narun nuurun Sala nuurin jahdi llahu linuurihi man ja faa?u wa jađribu Haahul PamӨaala linnasi wa Haahu bi kulli faj?in Saliim

fi bujuutin Paðina Haahu Pan turfaৎa wajuðkara fiiha smuhu jusabbiћu lahu fiiha bil вuduwwi 1 wal ?aas'aal

ridgaalun la tulhiihim tidzaaratun wal bajৎun ৎan ðikri llaahi wa iqami $s^{\complement} s^{\varsigma}$ alaati wa Piitaa?i $r$

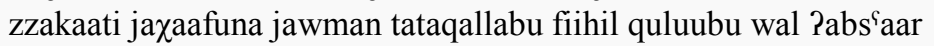


Phonetically, the $/ \mathrm{m} /, / \mathrm{n} /, / \mathrm{l} /$ and $/ \mathrm{r} /$ are called "liquids" but are also labeled as coronals in terms of their places of articulation except for the $/ \mathrm{m} /$ which is a bilabial sound. Moreover, all the endings of the verses are voiced. (Ateeq, 2009) claims that linguists and phoneticians describe $/ \mathrm{m} /, / \mathrm{n} /, / \mathrm{l} /$ and $/ \mathrm{r} /$ as semivowels. This claim is not supported by evidence as they are known as liquids but semivowels or as approximants as Ladefoged (1971) calls are /w, $\mathrm{j}$ and the English /r/. The Arabic /r/ is, however, called trill.

\subsubsection{The voiced sounds cluster}

This is the sequence of voiced consonant sounds as in the following example:

Table 7. The voiced sounds pattern (Ghafir, verses: 11-14)

Phonetic transcription
qaaluu rabbana Pamattana $\theta$ natajni wa Paћajajtana $\theta$ natajni fa 9 tarfnaa biðunuubinaa 1
fahal Pilaa $\chi$ uruudzin min sabiil

ðaalikum bi Pannahu Piðaa duৎia Haahu wahdahu kafartum wa Pin jufrak bihi $r$ tu?minuu falhukmu lillaahi ISalijji lkabiir

huwa llaðii juriikum aajatihi wa junazzilu lakum min ssmaa?i rizqan wa ma b jataðakkaru illa man juniib

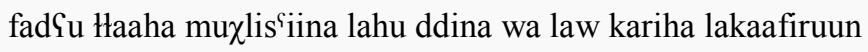

The /1/ and /r/ sounds are not only voiced but have also other common distinctive features such as coronal, anterior, and sonorant. Although $/ 1 /$ is a continuant consonant, $/ \mathrm{r} /$ is trill, which has a concomitant trilling and continuity as well. Ibrahim Anis as cited in Ateeq, (2009) indicates that the /1/ cannot be geminated with any other consonant in Quranic examples except with $/ \mathrm{r}$ / because they share the same place of articulation and a number of manners of articulation.

Table 8. Distinctive features of $/ 1 /$ and the $/ \mathrm{r} /$.

\begin{tabular}{lcc}
\hline Phonetic feature & 1 & $\mathrm{r}$ \\
\hline voicing & + & + \\
coronal & + & + \\
alveolar & + & + \\
liquid & + & + \\
\hline
\end{tabular}

2.1.6 The voicelessness sounds cluster

It is the sequence of a number of voiceless consonant sounds as explained below:

Table 9. The voicelessness sounds cluster (Taha, verses:11-14)

Phonetic transcription $\quad$ ending

fajaðaruhaa qaaৎan s`afs' ${ }^{\varsigma}$ afa

f

la tara fiiha Siwadzan wa la Pamta 
Table 9. shows that there is a sequence of sounds in the fawassil that are similar in the states of the glottis i.e. being voiceless, although they are different in their places of articulation. Ateeq (2009).

\subsection{Fāṣilah shift from the surrounding fawāṣil}

One of the Quranic phonetic phenomena is the shift of one fāșilah from the fawāșil in the subsequent verses. This sound shift occasionally comes either in the beginning of a group of verses, in the middle of a group of verses, or at the end of a group of verses. These different patterns are classified below:

\subsubsection{The initial sound shift cluster}

It is the deviation of the phonetic unit (fāṣilah) from the adjacent fawāṣil in some Quranic chapters or in a cluster of verses. Although the fășilah is different from the surrounding fawāṣil, the verses are in consort and consonance. The following example highlights this phonetic pattern:

Table 10. The initial sound shift pattern (Al-Buruj,verses:1-9)

\begin{tabular}{|c|c|}
\hline Phonetic transcription & ending \\
\hline wassama?i ðaatil buruuds & ds \\
\hline waljawmil maw̧uud & $\mathrm{d}$ \\
\hline wa Jaahidin wa mafhuud & $d$ \\
\hline 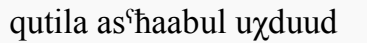 & $\mathrm{d}$ \\
\hline
\end{tabular}

annari ðaatil waquud

The starting verse in the above Quranic verses ends with /dz/ while the following verses undergo a sound shift to the /d/ sound. Ateeq (2009) postulates that this deviation is not odd and does not disturb the phonetic consonance of the verses. /dz/ is affricate, and affrication is an amalgamation of plosiveness and friction. Moreover, /dz/ and /d/ are close in the places of the articulation as both of them are articulated from the alveolar ridge. They are all coronal, voiced and audibly released sounds (qalqla). The following table summarizes the common distinctive features between $/ \mathrm{d} / \mathrm{and} / \mathrm{d} /$ :

Table 11. Distinctive Features of / $/ \mathrm{d} /$ and the /d/

\begin{tabular}{lcc}
\hline Phonetic feature & $\mathrm{d}$ & $\mathrm{d}$ \\
\hline voicing & + & + \\
coronal & + & + \\
alveolar & + & + \\
audibly release & + & + \\
plosive & + & + \\
friction & + & - \\
\hline
\end{tabular}


2.2.2 The fâșilah-medial shift cluster

This is a phonetic pattern where one fășilah in the middle of a cluster has a different ending sound from the preceding and the following fawāșil endings. This sound shift forms an undulation of a rhythmic phonetic melody. This type of sound shift is illustrated below:

(i) Undulation of voicing and devoicing

Table 12. Undulation of voicing and devoicing (Al-Inshiqaq, verses:8-13)

Phonetic transcription

ending

fasawfa juhaasabu hisaaban jasiira

$\mathrm{r}$

wajanqalibu Pilaa Pahlihi masruura

r

wa ammaa man Puutia kitaabuhu waraa?a đ`ahrih

$\mathrm{h}$

fasawfa jadৎuu $\theta$ ubuura

$\mathrm{r}$

wa jas`alaa saৎiira

r

Pinnahu kaana fii Pahlihi masruura

The $/ \mathrm{h} /$ sound is a medial sound shift from the surrounding fawāṣil endings. Ateeq (2009) claims that this sound shift forms melodious undulation of the voiced alveolar trill $/ \mathrm{r} /$ and the voiceless glottal fricative $/ \mathrm{h} /$. However, the $/ \mathrm{r} /$ sound is released into a vowel $/ \mathrm{a} /$, and the $/ \mathrm{h} / \mathrm{sound}$ is released into a vowel $/ \mathrm{i} /$ in connected recitation. This phonetic process of vowel release makes the real undulation between the vowel /a/ and the vowel /i/ in this cluster of verses.

(ii) Undulation of friction and affrication

Table 13. Undulation of friction and plosiveness, (Al-Al-Waaqi'ah, verses:3-5)

Phonetic transcription
Xaafiđatun raafiৎah

The sound shift is represented by the occurrence of the voiceless glottal fricative $/ \mathrm{h} /$, followed by the voiced postalveolar affricate $/ \mathrm{d} / \mathrm{l}$ and concluded with the voiceless alveolar fricative /s/. This peak gives a melodious undulation to the cluster of verses.

Close to this pattern is the sound shift from the voiceless dental fricative /f/ which comes in the middle of the two voiceless velar plosive sounds $/ \mathrm{k} /$. as shown in the table 14 . Ateeq (2009). 
Table 13 a. Undulation of friction and plosiveness, (Al-Thariyat, verses:7-9)

Phonetic transcription ending

was samaa?i ðaatil hubuk 난

Pinnakum lafii qawlin muxtalif $\quad$ ف

ju?faku Sanhu man Pufik $\quad$ k s

(iii) Undulation of Pharyngealization and depharyngealization

Table 14. Undulation of pharyngealization and depharyngealization, (Qaf, verses:12-14)

Phonetic transcription

ending

kaððabat qablahum qawmu nuuhin wa ?as`haabur rassi wa $\theta$ amuud

d

wa Saadun wa firৎawnu wa ixwaanu luut

$t^{\varsigma}$

wa as`haabul Pajkati wa qawmu tubbaৎ kulluy kaððabar rusula faћaqqa waSiid

d

The pharyngealized $/ \mathrm{t}^{\mathrm{f}} /$ comes between the two depharyngealized /d/ sounds, although they belong to the same place and manner of articulation. This sound shift gives phonetic ripple to the hearer.

2.2.3 The fāṣilah-final shift cluster

This is a phonetic pattern where one or two fawasșil at the end of a cluster have different endings from the previous fawāṣil.

(i) One fāṣilah shift

Table 15. Concluding undulation (Al-Masad, verses: $1-5)$

Phonetic transcription

ending

tabbat jadaa Pabii lahabin wa tabb

maaجarnaa Sanhu maaluhu wa ma kasab

sajs`laa naaran ðaata lahab

wa mra?atuhu hammalatal hatab 
The voiced bilabial plosive / $b$ / forms a phonetic set in the first four verses. However, we have a sound shift from the / $b /$ to the voiced alveolar plosive /d/. Yet, a phonetic harmony between the deviating sound /d/ and the pattern sound /b/ has been fulfilled as both sounds share other phonetic features i.e. voicing and plosiveness.

(ii) Two fawāṣil shift

Table 16. Undulation of voiced and voiceless pharyngeals (Al-Adiyat, verses:1-5)

Phonetic transcription

ending

wal Saadijaati ðৎabћa

fal muurijaati qadha

falmusiiraati s`ubha

fa PaӨarna bihi naqৎa

fa wsat' na bihi dzamৎa

In the above verses, the last two fawāșil shift from the voiceless pharyngeal fricative / $\hbar /$ to the voiced pharyngeal fricative $/ \mathrm{S} /$.

\subsection{Fawāṣil Internal change}

This is a pattern where the fawāsil are similar and identical, except for one internal sound within the structure of the fāssilah. This pattern is a frequently popular pattern in Quran. In this pattern, it is possible to find examples of verses that are not only similar in the fawāșil, but almost identical in the whole fāsilah i.e. examples of words that are similar in all components except for one sound such as /jubsiruun/ and /juns'aruun/. This pattern can be divided into two types: simple and compound as explained below:

\subsubsection{The simple change}

It is the similarity between two words in all phonetic units except for one sound.

Table 17. The simple change pattern (Al-Kahf, verses: 23,24)

Phonetic transcription
wa fadzdgarnaa $\chi$ ilaalahuma nahara
nahara

wa kaana lahuu $\theta$ amarun faqaala lis ${ }^{\varsigma}$ aahibihi wa huwa juhawirihuu Pana ak $\theta$ aru minka maalan wa aৎzzu nafara

The end-of-verse pauses /nahara/ and /nafara/ are identical in all segments except for /h/ and /f/, which are voiceless fricative. The voicelessness in $/ \mathrm{h} /$ and $/ \mathrm{f} /$ is juxtaposed to the devoicing of $/ \mathrm{n} /$ in the two words. Another example is:

Table 18. The simple change pattern (Al-Alaq, verses: 1,2)

\begin{tabular}{|c|c|}
\hline Phonetic transcription & ending \\
\hline Piqra? bismi rabbika allaðii $\chi$ alaq & xalaq \\
\hline
\end{tabular}


The two words are different in all the components except for one segment. The voiceless $/ \chi /$ and the voiced /S/. This contrast forms an audible undulation caused by the alternation between the voicing and the devoicing of the two segments. Another contrast between the two segments is in the places of articulation. $/ \chi /$ is uvular while $/ \mathrm{S} /$ is pharyngeal. The network of the contrast and similarity can be explained in the following table:

Table 19. Distinctive Features of Pharyngeals

\begin{tabular}{|c|c|c|c|c|c|c|c|}
\hline & cons & pharyng. & uvular & back & high & cont & voice \\
\hline$\chi$ & + & - & + & + & + & + & - \\
\hline 乌 & + & + & - & + & + & + & + \\
\hline
\end{tabular}

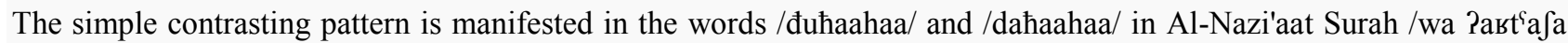

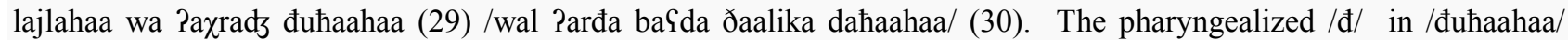
contrasts with the depharyngealized /d/ in /dahaahaa/. If we look closely to features of/d/ and /d/, we will see several common phonetic features.

Table 20. Distinctive Features of /d/ and /d/.

\begin{tabular}{|c|c|c|c|c|c|c|c|}
\hline & cons & pharyng. & coronal & anterior & strident & cont & voice \\
\hline đ & + & + & + & + & - & - & + \\
\hline d & + & - & + & + & - & - & + \\
\hline
\end{tabular}

Table 20. shows that both sounds are consonant, coronal, anterior, plosive and voiced. Another example is:

Table 21. Alternation between voicing and devoicing (Al-Jin verses:9-10)

Phonetic transcription $\quad$ ending

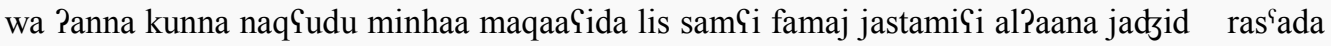
lahuu Jihaabr ras`ada

wa Panna la nadir PaJarrun Puriida biman fil Parđi Pam Paraada bihim rabbuhum rasada

In the verses, the fawāṣil are $/ \mathrm{ras}^{\varsigma} \mathrm{ada} /$ and / $\mathrm{ra}$ ada/. The two words are identical in all sounds except for $/ \mathrm{s}^{\varsigma} /$ and $/ \mathrm{J} /$. The two consonant sounds are voiceless, fricative, alveolar and postalveolar, coronal and strident. This similar features give a special wave of rhythm to the verses as we see in the syllabification of the two words below: 
Table 22. Syllabification of words

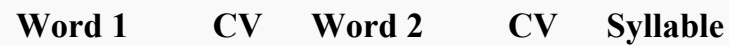

$\begin{array}{lllll}\mathrm{r} & \mathrm{C} & \mathrm{r} & \mathrm{C} & \text { Short syllable starting with voicing and trilling }\end{array}$

$\begin{array}{llll}\text { a } & \text { V } & \text { a } & \text { V }\end{array}$

$\mathrm{s}^{\varsigma} \quad \mathrm{C} \quad \mathrm{S} \quad \mathrm{C} \quad$ Short syllable starting with voicelessness and friction

a

C a

C

d $\quad$ V $\quad$ d $\quad$ V heavy closed syllable starting with voicing

aa

C aa

C

Another example is:

Table 23. The compound contrasting sound pattern (Saba, verses: 46,47)

Phonetic transcription ending

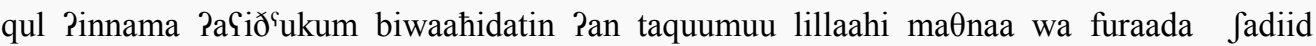
Oumma tatfakkaruu ma bis`aahibikum min dzinnatin ?in huwa Pillaa naðiirul lakum bajna jadai Gaðaabin Jadiid

qul ma saPaltukum min Padzrin fahuwa lakum Pin Padzrija Pilla Sala ałtaahi wa huwa Galaa kulli Jaj?in Jahiid

The words / Sahiid/ and / Jadiid/ are identical except for $/ \mathrm{d} /$ and $/ \mathrm{h} / \mathrm{which}$ contrast in four phonetic features: the contrast between voicing and devoicing, the contrast between friction and plosiveness as shown below:

Table 24. Distinctive Features of $/ h /$ and $/ d /$.

\begin{tabular}{|c|c|c|c|c|c|}
\hline & syllabic & coronal & anterior & cont & voice \\
\hline $\mathrm{h}$ & - & - & - & + & - \\
\hline $\mathrm{d}$ & + & + & + & - & + \\
\hline
\end{tabular}




\title{
2.3.2 The compound change
}

It is a pattern which comprises two fawāssil that are identical in all phonetic components except for one consonant and one or more vowels as in the following cluster:

Table 25. The simple matching sound pattern (Al-A'raf, verses:197-198)

Phonetic transcription

Ending

wal laðiina tadৎuuna min duunihi la jastat'iiৎuuna nas'rakum wa laa anfasahum jans ${ }^{\complement} u r u u n$

jans'uruun

\begin{abstract}
wal ladiina tad una min duunihi la jastat
\end{abstract}
wa in tadৎuuhum ilal huda la jasmaৎuu wa traahum janð`uruuna ilaika wa hum la jubs ${ }^{\varsigma}$ iruun

jubs'iruun

(1,

From the above verses, it is obvious that the fawāṣil /jans' uruun/and /jubsiriruun/ are identical in all the phonetic components except for one voiced bilabial stop sound $/ \mathrm{b} /$ and the voiced alveolar nasal $/ \mathrm{n} /$ as well as to some differences in vowels. When the two words are divided into syllables, we can observe that components of agreement are overwhelming as shown below:

Table 26. Syllabification of words

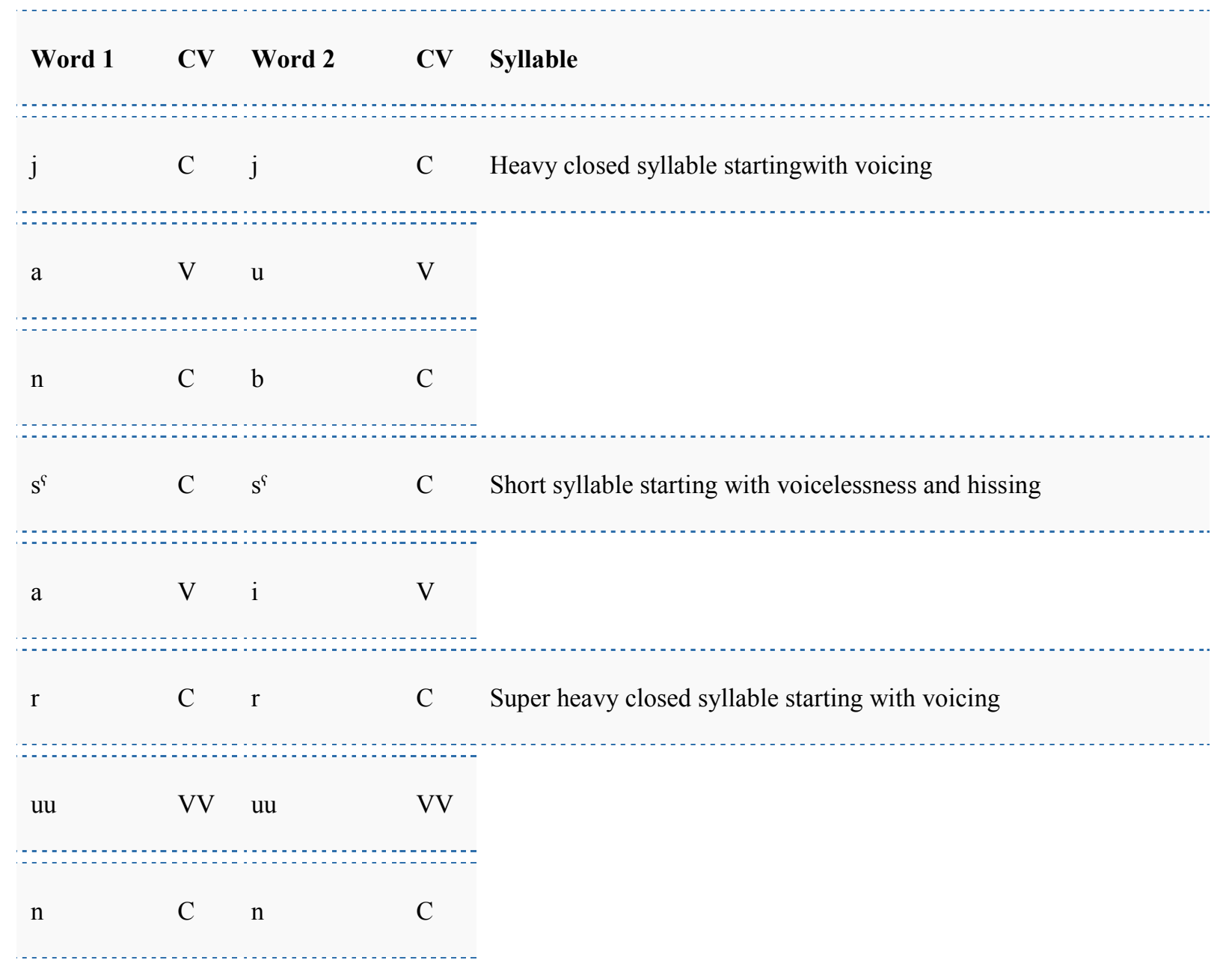

The short syllable that comes between the two heavy and super heavy syllables starts with a voiceless sound while the other two syllables start with voiced sounds. This alternation between voicing and devoicing gives the verses a contour of melodious undulation.

\subsection{The semantically-oriented sounds}

Every chapter in the Quran ends with a certain frequency of particular sounds. It goes without saying that the repeated focus on particular sounds in each chapter entails certain semantically-oriented features. For example, SuratAl-Qmar 
(the moon) comprises 55 verses, all of which end with the voiced alveolar trill /r/. Surat Al-Qmar is a "a horrifying campaign against the unbelievers as much as it is deep tranquility on the hearts of the believers" Qutb, S. (1976:V4:88). This theme is transmitted through the frequent rhythm of the sound /r/ at the end of the unique fawāșil of this Surah that are not available in other chapters of the Quran such as /mustamir, qudir, muzdadzar, nuður, munhamir, dusur/ etc. In this section, some semantically-oriented function of the fawāșil will be discussed. The semantic function of the /s/ sound entails (i) uncertainty, (ii) listening obediently to Satan who is whispering to someone.

\begin{tabular}{|c|c|c|}
\hline Phonetic transcription & sound & Semantic function \\
\hline qul Paৎuuðu birabbi nnaas & $\mathrm{s}$ & Whisper \\
\hline maliki nnaas & s & Murmur \\
\hline Pilaahi nnaas & $\mathrm{s}$ & listening obediently \\
\hline min Jarri lwaswaasi lqannas & $\mathrm{s}$ & Lightness \\
\hline $\begin{array}{l}\text { Pallaðii juwaswisu fii } \\
\text { s'udduri nnaas }\end{array}$ & $\mathrm{s}$ & Weightlessness \\
\hline min aldzinnati wannaas & $\mathrm{s}$ & Uncertainty \\
\hline
\end{tabular}

This chapter ends with the voiceless alveolar fricative /s/ and it starts with seeking refuge in the Lord of mankind from the evil of the repeated whisperer. Thus, there is an allusion to the evil of the Satan who whispers in a retreating way causing doubt and uncertainty. All these meanings are conveyed through the repeated occurrence of the sound /s/. Another example is from Surat Al-Qari'a which has one topic i.e. the Day of Judgment.

Table 28. Possible shadows of meaning of /h/ sound (Al-Qari'ah, verses: 1-6)

\begin{tabular}{|c|c|c|}
\hline Phonetic transcription & sound & $\begin{array}{l}\text { Semantic } \\
\text { function }\end{array}$ \\
\hline Palqaariৎah & $\mathrm{h}$ & Fear \\
\hline malqaariSah & $\mathrm{h}$ & Anxiety \\
\hline $\begin{array}{l}\text { Wa maa Padraaka mal } \\
\text { qaariৎah }\end{array}$ & $\mathrm{h}$ & Distraction \\
\hline fa $\quad$ Pummuhuu & $\mathrm{h}$ & Fright \\
\hline $\begin{array}{l}\text { wa maa Padraaka maa } \\
\text { hijah }\end{array}$ & $\mathrm{h}$ & Fatigue \\
\hline naarun haamijah & $\mathrm{h}$ & Bewilderment \\
\hline
\end{tabular}


The fawāṣil of the verses which narrate the Day of Judgment in the Quran usually end with /h/. /h/ is voiceless glottal fricative which indicates fear, distraction, loss of breath and bewilderment. The names that are given to the Day of judgment in the Quran mostly end with /h/ (alqijaamah, alwaaqiSah, alPaazifah, arraadgifah, arraadifah, alкаafijah, at $t^{\uparrow} t^{\uparrow}$ aammah, as $\left.{ }^{\uparrow} s^{\Upsilon} a a \chi \chi a h\right)$. The Day of Judgment is described in Quran as void and people run breathlessly from one place to another as we are told by the Quran: "Racing ahead, their heads raised up, their glance does not come back to them, and their hearts are void", (Surat Ibrahim, verse:43). Thus, the sound /h/ conveys the dismay and trepidation that the Day of Judgment causes. Another example is from Surat Al-'adiyat.

Table 29. Possible shadows of meaning of $/ \hbar /$ sound (Al-'adiyat, verses: $1-5$ )

\begin{tabular}{|c|c|}
\hline Phonetic transcription & ending \\
\hline wal Saadijaati ð`abћa & $\hbar$ \\
\hline fal muurijaati qadha & $\hbar$ \\
\hline falmusiiraati s`ubћa & $\hbar$ \\
\hline fa PaӨarna bihi naqৎa & ৎ \\
\hline fa wsat' na bihi dzamৎa & $\varsigma$ \\
\hline
\end{tabular}

Surat Al-'adiyat starts with an oath by the horses that Arabs are familiar with their sounds, particularly in the battles. 'By the racers, panting'; When the racers run, they produce a sound which is identical to the Arabic sound / $\mathrm{h} /$. 'And the producers of sparks [when] striking'. When the racers run, they may produce some sparks /qadh/. The sound of the sparks are close to the sound $/ \hbar /$. Thus this chapter displays some onomatopoeic relationship between the sound/ $\mathrm{h} / \mathrm{and}$ the meaning of the fawāṣil of these verses.

\section{Conclusion}

Based on the above phonetic and semantic analysis, it can be claimed that the Quranic fawāșil are of different types:

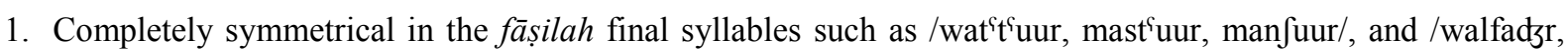

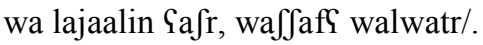

2. Semi-symmetrical in the fāṣilah final syllables such as /arraћmaan arrahiim, maaliki jawm addiin/. The sounds $/ \mathrm{m} /$ and $/ \mathrm{n} /$ are semi-symmetrical as they are close in their places of articulation. However, they share other distinctive features such as being anterior, voiced and nasal. Another example of this type is /walquran almadziid, Jaj?un Sadziib/. The sounds /d/ and /b/ do not share the same place of articulation. However, they both share voicing and being anterior.

3. The fawāṣil can share the same foot and rhythm, as in /surrurn marfuuYah, wa Pkwaabun mawd'uuYah/.

4. The fawāsil can also have different foot and rhythm. However, they are similar in some sounds such as /maa lakum la tardzuuna lillaahi waqaara, wa qad $\chi$ alaqakum Pat $^{\uparrow}$ waara/. /waqaara and / at $^{\varsigma}$ waara/ have different feet but they are similar in the last two sounds.

5. The fawāșil are similar in the foot but different in sounds such as /almustaqiim, almustabiin/.

6. The fawāṣil are similar in the last two sounds such as /fa Pamma aljatiima fala taqhar, wa Pamma assa?ila falaa tanhar/. /har/ are similar in the two fawāsil. / Palam nafrah laka s`adrak, wa wad'ånaa Sanka wizrak. /rak/ are repeated in the two fawāșil. Other examples are /wat ${ }^{\varsigma} t^{\varsigma}$ uur wa kitaabun mast ${ }^{\varsigma}$ uur/ and /fa?iðaa hum mubsiruun, Oumma la juqs'iruun/.

7. We can also conclude that some chapters end with a different fāṣilah from all the previous fawāṣil. An example of this is Al-Dhuha /fa?amma aljatiima fa la taqhar, wa Pammas saa?ila fala tanhar, wa ?amma binSmati rabbika fahaddi $\theta$.

\section{Acknowledgements}

I would like to express my thanks and gratitude to professor Hussein Abdul-Raof for his assistance and proofreading during the earlier drafts of this paper.

\section{References}

Abdel-Haleem, M. (2001). Understanding the Quran: Themes and Style. London: I.B. Tauris.

Abdul-Raof, H. (2012). Theological Approaches to Qur'anic Exegesis: A Practical comparative contrastive Analysis. London and new York: Routledge.

Al-Baqillani, A. (1997). I'jaaz al-Quran. Cairo: Dar Al-Ma'arif.

Al-Rummani, A. (1956). Al-Nukat fii I'jaaz Al-Quran Al-Kareem. Cairo: Dar Al-Ma'raif.

Ateeq, O. A. (2009). Al-Osloobiyyah Al-Sawtiyyah fil-Fawaasil Alquraniyyah. Journal of Al-Manarah, 16(3). Mafraq 
Al-Zarkashi, B. (1957). Al-Burhaan fii Uluum Al-Quran. Cairo: Dar Al-Turaath.

Anis, I. (1963). Aswaat Allughah 'Ind Ibn Sinaa. Proceedings of the Arabic LanguageConference, Cairo.

Anis, I. (1971). Al-Aswaat Allughawijjah. Cairo: The Anglo-Egyptian Press, (fourth ed.).

Anis, I. (1976). Dalaalat Al-Alfaath. Cairo: The Anglo-Egyptian Press.

Arberry, A.J. (1988). Oxford World's Classics. New York: Oxford University Press, p.xiii. First published 1955 by Allen and Unwin Ltd.

Bint Ashati'. A. (1971). Al-I'jaz Al-Bayani Lil-Quran. Qairo: Dar Alm'aref.

Boullata, Issa (1988). 'The Miraculous Inimitability of the Holy Qur'an throughout history. In Approaches to the History of the Interpretation of the Quran. Edited by Andrew Rippin. Oxford the Clarendon Press.

Boullata, I. (2006). 'The Rhetorical Interpretation of the Qur'an: I'jaz and related topics'. In Approaches to the History of the Interpretation of the Quran. Edited by Andrew Rippin. Oxford: The Clarendon Press.

Lawrence, B. (2005). Approximating saj' in English Renditions of the Qur'an: A Close

Reading of Sura 93 (al-Duhā) and the basmala. Journal of Qur'anic Studies.

Neuwirth, A. (1993). 'Images and Metaphors in the Introductory Sections of the Makkan's Surahs'. In G.R. Hawting and Adbul-Kader A. Shareef (eds), Approaches to the Quraan, (London and New York, Routledge, pp 20-1.

Omer, A. (1999). Fāșilah in the Qur'an: Word, Context and Meaning. Journal of Qur'anic Studies, 1(1), 238-220.

Qutb, S. (1976). Fi Thilal Al-Quran. Cairo: Dar Al-Shorook.

Toorawa, S. (2002). Seeking Refuge from the Evil: 'The Power and Portent of the Closing Chapters of the Quran'. Journal of Qur'anic Studies, 4(2), 54-60

Toorawa, S. (summer 2009). Hapless Hapaxes and Luckless Rhymes. The Qua'an as Literature, Religion \& Literature,41(2), 221-227

Toorawa, S. M. (2006). The Inimitable Rose', being Qur'anic saj 'from Sūrat al-Ḍuhā to Sūrat al-Nās (Q. 3-114) in English Rhyming Prose. Journal of Qur'anic Studies, 8(2), 143-155. 